\title{
Two New Records of Siphonophores (Cnidaria: Hydrozoa: Siphonophora) in Korean Waters
}

\author{
Jung Hee Park* \\ Department of Life Science, College of Natural Sciences, the University of Suwon, \\ Gyeonggi-do 445-743
}

\begin{abstract}
Some physonect and cystonect siphonophores were collected from the East Sea $\left(36^{\circ} 30^{\prime} 124^{\prime} \mathrm{N}\right.$ and $130^{\circ}$ $06^{\prime} 446^{\prime} \mathrm{E}$ ) with horizontal plankton net on May and Oct. 2001. Among them the following two species were turned out to be new to the Korean fauna: Bathyphysa grimaldii Bedot, 1893; Agalma okenii Eschscholtz, 1825.
\end{abstract}

Keywords: taxonomy, Siphonophora, Hydrozoa, Korea

\section{INTRODUCTION}

Siphonophores are highly polymorphic animals and are readily distinguishable from the free-swimming medusoid stages of other hydrozoans. Approximately 150 species of siphonophores currently are recognized. The order Siphonophora divided into three suborders on the basis of the presence or absence of either an apical gas field float, the pneumatophore, or of swimming bells, nectophores which are grouped together to form the nectosome. The suborder Cystonectae possess only the pneumatophore; The Physonectae possess both a nectosome and the pneumatophore; while the Calycophorae only develop a nectosome (Kirkpatrick and Puch, 1984).

The Korean siphonophore fauna known so far composed of eight species, five genera, four families in two suborders; four species in Diphyidae, two in Abylidae of the suborder Calycophorae and one in Porpitidae, one in Physaliidae of the suborder Cystonectae (Park, 2002, 2007; Park and Song, 2004; Park and Won, 2004, 2005).

Some physonect and cystonect siphonophores were collected from the East Sea $\left(36^{\circ} 30^{\prime} 124^{\prime} \mathrm{N}\right.$ and $\left.130^{\circ} 06^{\prime} 446^{\prime} \mathrm{E}\right)$ with horizontal plankton net on May and Oct. 2001. They were preserved in $5 \%$ neutral formalin and identified on the basis of the morphological characters. The pictures in figures were taken under the Nikon SMG-U stereomicroscope. The photograph of whole body were taken with $\mathrm{Ca}-$ non EOS 300D digital camera.

\footnotetext{
*To whom correspondence should be addressed

Tel: 82-31-220-2480, Fax: 82-31-220-2484

E-mail: jhpark5@suwon.ac.kr
}

\section{SYSTEMATIC ACCOUNTS}

Phylum Cnidaria

Class Hydrozoa

Order Siphonophora

Suborder Cystonectae Haeckel, 1888

${ }^{1}$ *Family Rhizophysidae Brandt, 1825

2*Bathyphysa grimaldii Bedot, 1893 (Fig. 1A-C)

Bathyphysa grimaldii Kawamura, 1954, p. 120, textfig. 2, pl. 5, figs. 1-3, pl. 6, figs. 1-2, pl. 7, figs. 1-7.

Material examined. The East Sea $\left(36^{\circ} 30^{\prime} 124^{\prime} \mathrm{N}\right.$ and $130^{\circ}$ $\left.06^{\prime} 446^{\prime} \mathrm{E}\right), 15$ Oct. 2001 (J.H. Won).

Description. Colonies composed of various fragments, light salmon color in formalin. Contents in gastrosiphon dark brown color. Apical pneumatophore spindle shaped, without any hypocystic villi in its interior, with some minute polygonal pigments of faded red near apex. Stem variable in diameter according to constriction. Many bladder-form siphons aggregate densely in ventral side of pneumatophore.

Remarks. Because the twisting of colony is very hard, it is difficult to discriminate the zooids. There are many kinds of siphons by modification: hook-shaped, rod-shaped, trumpet-shaped and donut-shaped siphons. This species is similar to B. japonica Kawamura, 1942 (see Kawamura, 1954) in the shape of colony and spindle-shaped pneumatophore. But it is distinguished from the latter by its lesser dimension of several zooids and the form of the siphons and pneumatosiphons.

Distribution. Pacific Ocean.

$1 *$ 거품뿌리관해파리과, ${ }^{2 *}$ 그리말디거품관해파리 

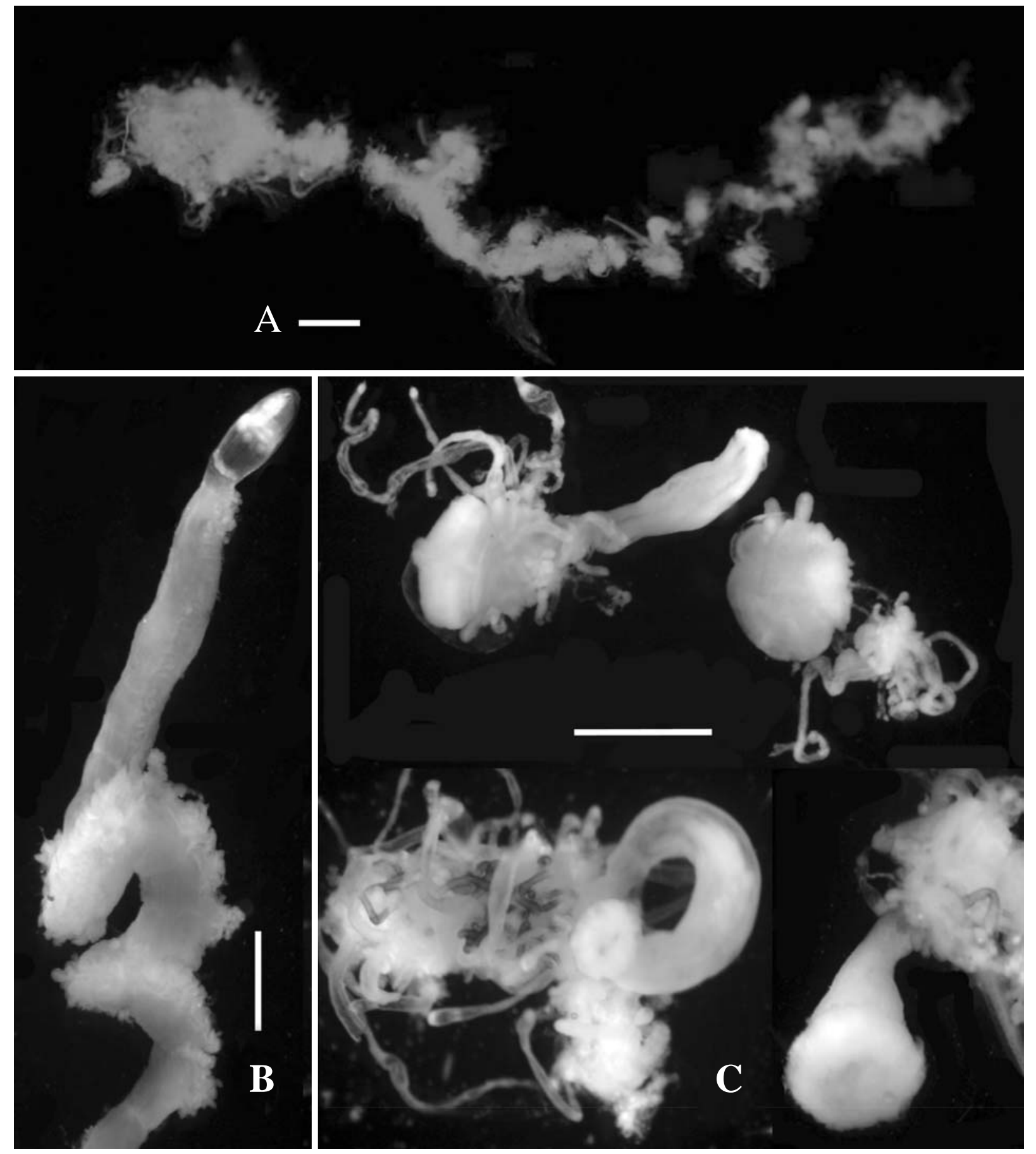

Fig. 1. Bathyphysa grimaldii. A, fragments of colony; B, spindle-shaped pneumatophore; C, variable types of siphons. Scale bars=2 $\mathrm{mm}(\mathrm{A}), 1 \mathrm{~mm}(\mathrm{~B}-\mathrm{C})$.

$1 *$ Suborder Physonectae Haeckel, 1888

2*Family Agalmidae Brandt, 1835

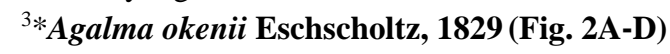

Agalma okenii Eschscholtz, 1829; Kawamura, 1954, p. 107, pl. 2, figs. 1-7; Nabikawa and Soyama, 2000, p. 77.

Agalma okeni: Totton and Bargmann, 1965, p. 53, pl. 9,

\footnotetext{
$1 *$ 거품관해파리아목, ${ }^{2}$ 황금관해파리과, ${ }^{3 *}$ 오켄황금관해파리
} 

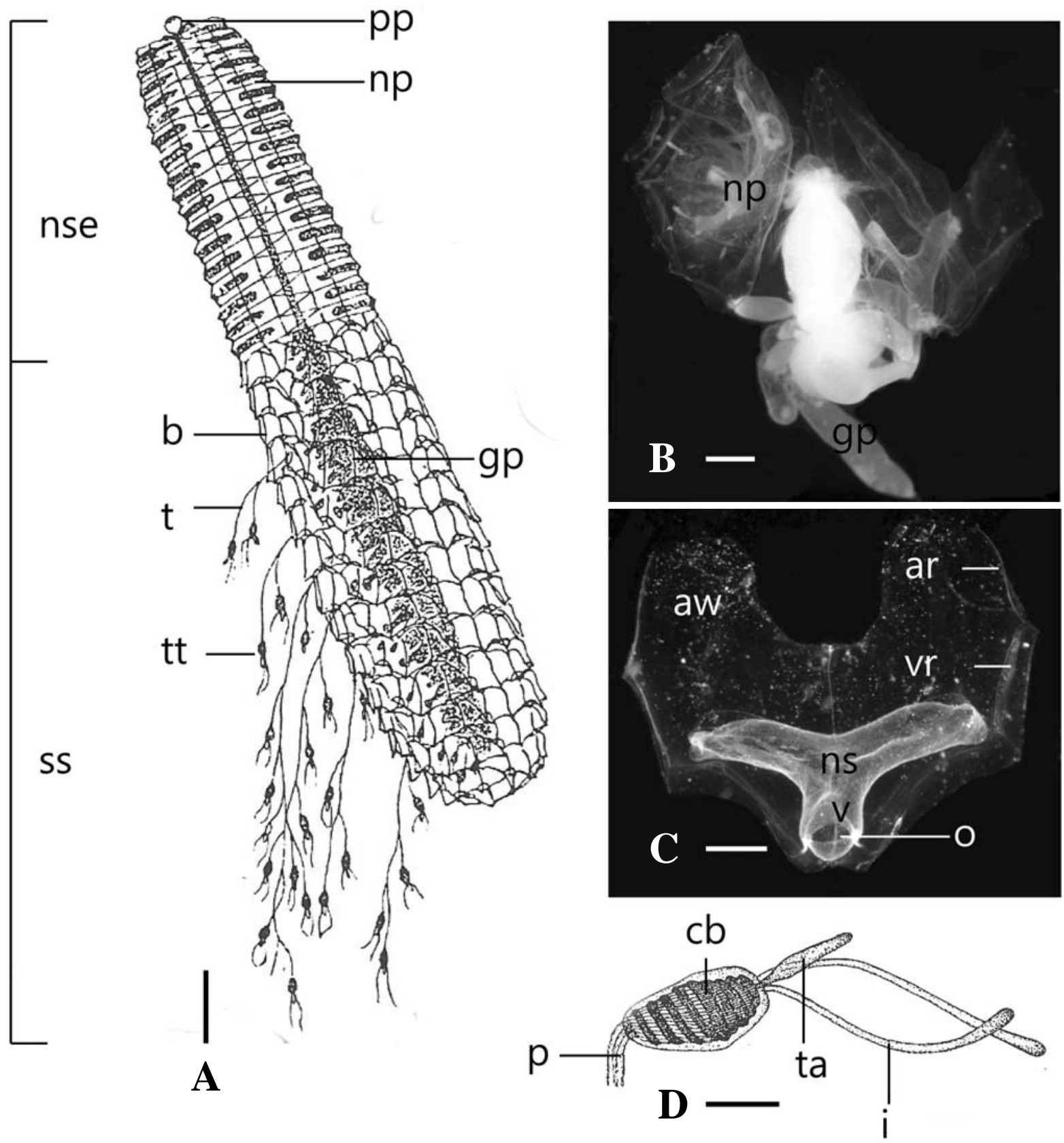

Fig. 2. Agalma okenii. A, whole animal (b, bract; gp, gonophores; np, nectophore; nse, nectosome; pp, pneumatophore; ss, siphosome; t, tentacle; tt, tentillum) (cited from Kawamura, 1954 ); B, nectophores with gonophores (np, nectophore; gp, gonophores); C, upper view of nectophore (aw, apical wing; ar, apical ridge; ns, nectosac; o. ostium; v, velum; vr, vertical ridge); $D$, tentillum (cb, cnidoband; $i$, involucres; $p$, peduncle; ta, terminal ampulla) (cited from Kawamura, 1954). Scale bars $=10 \mathrm{~mm}(\mathrm{~A})$, $1 \mathrm{~mm}(B-D)$.

gigs. 1-14, pl. 11, fig. 3; Pugh, 1999, p. 481, figs. 3.7, 3.23; Shangwu et al., 2002., p. 68, fig. 25A-B.

Material examined. East Sea $\left(36^{\circ} 30^{\prime} 124^{\prime} \mathrm{N}\right.$ and $130^{\circ} 06^{\prime}$ 446’E), May 7, 2001 (J.H. Won).
Description. Colony composed of nectosome and siphosome, cylindrical rod form with its lower and upper ends round. Nectosome composed of nectophores, and siphosome composed of compact grouping of zooids. According to Totton and Bargman (1965), nectosome dodecagonal body, 
slightly tapered above, where lies small egg-shaped pneumatophore with reddish brown pigment at its apex. Nectophore with apical lateral ridge without distinct notch and with one or two vertical lateral ridges, but lateral ridge absent. Nectosac Y-shaped. Lateral radial canal distinctly looped.

Remarks. Entire animals were not collected, but the shape of the characteristic nectophore was used its identification. This species similar to A. elegans (see Totton and Bargmann, 1965) in the shape of colony and tentillum. But this species is differ from the latter by the shape of nectophore. The end of its apical wing of this species is round and its nectosac is distinct Y-shaped, while the end of apical wing of A. elegans is angled and the nectosac is T-shaped.

Distribution. Common species in the warmer regions of three great oceans, Pacific Ocean, Indian Ocean and Atlantic Ocean.

\section{REFERENCES}

Eschscholtz, F., 1829. Systema der Acaleopen. Berlin, pp. 1190, pls. 1-16.

Kawamura, T., 1954. A report on Japanese siphnophores with special references to new and rare species. J. Shiga Prefectural Junior College, Ser. A, 2(4): 99-129, pls. 1-7.

Kirkpatrick, P.A. and P.R. Puch, 1984. Siphonophores and
Velellids. Linn. Soc. Lond., pp. 1-154.

Namikawa, H. and I. Soyama, 2000. Jellyfish in Japanese Waters. Tokyo, Japan, pp. 1-118.

Park, J.H., 2002. Two new records of Siphonophora (Hydrozoa) and Semaeostomeae (Scyphozoa) in Korea. Korean J. Syst. Zool., 18(1): 53-58.

Park, J.H., 2007. Five new records of hydromedusae (Cnidaria: Hydrozoa) in Korea. Korean J. Syst. Zool., 23(2): 175-181.

Park, J.H. and J.I. Song, 2004. Two new records of hydromedusae (Cnidaria: Hydrozoa) in Korea. Korean J. Syst. Zool., 20(1): 31-37.

Park, J.H. and J.H. Won, 2004. Three new records of hydromedusae (Cnidaria: Hydrozoa) in Korea. Korean J. Syst. Zool., 20(2): 179-184.

Park, J.H. and J.H. Won, 2005. Two new records of siphonophores (Hydroida: Siphonophora) in Korea. Korean J. Syst. Zool., 21(2): 201-205.

Pugh, P.R., 1999. Siphonophorae. In: South Atlantic Zooplankton Vol. 1 (Ed., D. Boltovskoy). pp. 481, 495, 498. Bakhuys Publisher, Leiden.

Totton, A.K. and H.E. Bargmann, 1965. A sysnopsis of the Siphonophora. Br. Mus. Nat. Hist., Lond., pp. 1-230, pls. $1-11$.

Shangwu, G., H. Sueshin and Z. Shimei, 2002. Fauna Sinica, Invertebrata Vol. 27. Phylum Cnidaria. Science Press, Beijing, China, pp. 68-69.

Received February 10, 2010 Accepted March 11, 2010 